\title{
Quintus of Smyrna and Virgil - A Matter of Prejudice
}

\author{
ALAN W. JAMES
}

\section{History of the Debate}

The Greek epic poem by Quintus of Smyrna is the only large-scale poetic narrative of much of the traditional story of the Trojan War surviving from antiquity. With 8,800 lines in fourteen books, it is rather more than half the length of the Iliad. It tells the story from the end of the Iliad to the beginning of the Odyssey, and so covers the same ground as several of the lost epics of the Epic Cycle, the Aethiopis, the Little Iliad, the Sack of Ilium (Ilioupersis) and part of the Returns (Nostoi). It was probably the recent loss of these poems that motivated Quintus' undertaking, though the question of whether they were still available to him has been a matter of sustained scholarly debate. ${ }^{1}$ Certainly the fact that he successfully replaced them was the main reason for his work's survival. The success with which he reproduced the language and style of the Homeric epics and avoided obvious anachronisms led to similar debate about his date. It is only recently that external evidence has come to light that has made it possible to place Quintus' floruit firmly in the second half of the third century A.D. ${ }^{2}$

Known by the Latin title Posthomerica, Sequel to Homer, Quintus' epic was rediscovered by Cardinal Bessarion in a Greek monastery near Otranto soon after the fall of Constantinople in 1453, as was recorded by the Greek émigré scholar Constantine Lascaris in 1496. That is why he was wrongly named Quintus of Calabria in editions of his work down to the eighteenth century, notwithstanding an autobiographical passage recording his inspiration by the Muses at Smyrna (12.306-313). ${ }^{3}$ Lascaris deduced from his Latin name that he must have lived within the long period of Roman rule in Asia Minor. ${ }^{4}$ An attempt to date him more narrowly was made by the German Hellenist Lorenz Rhodomann (1546-

1 See Gärtner (2005) $28 \mathrm{n} .10$ for references.

2 See James / Lee (2000) 1-9.

3 For a metapoetic rather than autobiographical interpretation of this passage, see the contribution of S. Bär in this volume.

4 See James / Lee (2000) 1-9. As for Quintus' Latin name, we have a recorded protest against the inclusion of Latin names in an official document written in Ionic Greek at Smyrna in the first century A.D.: Philostr. VA 4.5. 
1606). In 1604 he published the first truly critical edition of the Greek text with his own Latin translation. In the preface to this ${ }^{5}$ he deduced from the similarity of his style to that of Colluthus and Nonnus that Quintus lived in the fifth century A.D., and saw support for this dating in Quintus' indebtedness to Ovid for the contest over Achilles' armour and to Virgil for the destruction of Troy. He also noted the theoretical possibility that the indebtedness was in the opposite direction.

The alternative explanation for similarities in the treatment of these episodes, at least in the case of Virgil and Quintus, that both poets used the same sources, was briefly stated by Thomas Tychsen, in the introduction to his edition, the first substantial improvement on that of Rhodomann published two hundred years earlier. ${ }^{6}$ A further alternative, that of denying any influence at all, was stated with similar brevity by Hermann Köchly, after comparing the treatment of the woodenhorse episode by Quintus in book 12 and by Virgil in Aeneid 2, in the prolegomena to his edition of $1850 .^{7}$ The alternative noted by Rhodomann, that Virgil and others could actually have been indebted to Quintus, was then developed in an interesting form by Frederick Paley in a paper, one of a series on related topics, ${ }^{8}$ published in 1876 (London), titled Quintus Smyrnaeus and the Homer of the Tragic Poets. He states: "[W]hoever the poet was, $[\ldots]$ it is certain that he has handed down to us - how far altered or re-arranged we cannot positively say - the very poems which Virgil and Propertius repeatedly translate [...]" ${ }^{\prime 9} \mathrm{He}$ means the early epics of the Cycle, and he further observes: "On the whole, it is hardly too much to say, that if the Posthomerica of Quintus had come down to us as an original poem with the traditional authority of our Homer, and the Iliad and the Odyssey had been called [...] "post-homeric," the position of the poems, as far as language and matter are concerned, would have been reversed." 10

A comparison of the main episodes common to the Posthomerica and the Aeneid was included by Richard Heinze in his Virgils epische Technik. ${ }^{11}$ First published in 1903, its status as a classic of Virgilian scholarship was reflected by publication of an English translation ninety years later, and this circumstance could give the impression that its treatment of the present topic was the last word. He duly observes the important difference as well as the striking similarity of some details between the two versions of the roles of Sinon, Laocoon and

\footnotetext{
5 Rhodomann (1604), preface without page numbers.

6 Tychsen (1807) LXXVII.

7 Köchly (1850) XXVI.

8 See Sandys (1908) 409-410.

9 Paley (1876) 2.

10 Paley (1876) 7.

11 Heinze $\left({ }^{3} 1915\right) 63-81$.
} 
Cassandra in relation to the admission of the wooden horse. But the possibility that Quintus chose not to include many prominent features of Virgil's narrative, if known to him, is rejected as being inconsistent with an author who otherwise simply compiled what was available to him. In other words, a fundamental assumption is made without any attempt to justify it. The same reasoning is even applied to the release of the winds by Aeolus to cause a storm at sea as narrated in Aeneid 1.50-107 and Posthomerica 14.466-496, where the differences are insignificant compared with the sustained similarity.

The foremost exponent of the case for direct dependence of Quintus on Virgil, Rudolf Keydell, began a series of publications with a review of Heinze's treatment of the matter. ${ }^{12}$ Against the hypothesis of Heinze and others that the distinctive features common to Virgil's and Quintus' versions of the woodenhorse episode were not invented by Virgil but derived from a lost Hellenistic epic, he argued that it would lead to the implausible conclusion that Virgil followed his source very closely. He also argued that Quintus' relatively close reflection elsewhere of a minor episode in the Aeneid (9.505-518, use of a testudo as at Q.S. 11.356-407) proves that he knew the Aeneid well and justifies the assumption of Virgil's direct influence in cases of less precise correspondence. However, Keydell had a low estimation of Quintus' ability, seeing the relative simplicity of his version of the wooden-horse episode as due to his incapacity for complex narrative. This prejudice led to a questionable assumption of Virgil's influence in another case. Acknowledging the dramatic superiority of Quintus' version of the arrival and intervention of Neoptolemus in Posthomerica 7 over earlier known versions, he believed it could only be due to the influence of action in Aeneid 10 that is only loosely parallel - the arrival of Aeneas just in time to save his camp from attack.

For the past fifty years Quintus studies have been dominated by the work of Francis Vian. His relevant publications are a volume of studies, Recherches, published in 1959, and the three volumes of his Budé edition, published between 1963 and $1969 .{ }^{13}$ In his exhaustive treatment of sources he followed Heinze and sought to rebut Keydell's arguments. In his Recherches he concludes thus: "Le fait le plus remarquable est que QS, dans ses quatre derniers livres, et Virgile offrent des correspondances multiples et variées. A moins d'imaginer un concours bien improbable de rencontres fortuites, elles supposent l'existence d'une vaste composition, beaucoup plus développée que ne le serait un résumé mythographique: une narration, versifiée sans doute, du Sac de Troie [...] / [...] Pourquoi craint-on d'ôter aux Latins toute originalité en accordant que les épiques grecs

12 Keydell (1931) 71-80; (1954) 254-256; (1961) 278-284; (1963) 1271-1296.

13 Vian (1959a) 17-109; (1963; 1966; 1969) passim. 
tardifs conservent une image assez exacte de certains de leurs modèles?"14 He sticks to this hypothesis throughout the commentary that accompanies his edition and translation, but in the general introduction of the first volume he makes the following surprising concession: "Assurément, on ne saurait affirmer que Quintus ignorait les Latins; mais, même si par endroit ces lectures ont laissé des traces, la mise en œuvre a été opérée avec des matériaux grecs et d'après la technique traditionelle de l'imitation. [...] Quel que soit ce Pisandre, il n'est pas illégitime de penser qu'il a été l'une des sources de Quintus, et peut-être celle qui serait, plus que nulle autre, responsable du «mirage latin»." 15 In a review of the last volume of Vian's edition Hartmut Erbse made these observations: 'The burden of proof rests with anyone who argues that Virgil could have been ignored by an epic poet of Quintus' time who treated the fall of Troy. Vian's repeated appeal to hypothetical lost sources common to Virgil and Quintus would only be justified if it were actually proved that the extant witnesses of the tradition could not depend on one another.'16

Of the two full-scale commentaries on individual books of the Posthomerica published subsequently, that of Malcolm Campbell on book 12 follows Heinze and Vian in the matter of Latin sources. ${ }^{17}$ But whereas Vian showed a just appreciation of Quintus' distinctive merits, Campbell outdid Keydell in denigrating him, whilst bestowing extravagant praise on Virgil. This produces observations like the following: "Those who insist that Q[uintus] is indebted to V[irgil] must content themselves with something far short of an Aeneid; a summary [...], a work drained of poetic vitality."18 The other commentary, on book 5, by Alan James and Kevin Lee, impinges on the present topic for its treatment of the question whether Quintus was indebted to Ovid for the contest over Achilles' armour, touched on already by Rhodomann, or, more precisely, to the rival speeches by Ajax and Odysseus at Metamorphoses 13.1-381 for those at Posthomerica 5.180-317. ${ }^{19}$ Analysis of Quintus' version of Ajax's main speech reveals that of its fourteen points thirteen have counterparts in Ovid's version, some with verbal similarity, and four points are in the same sequence in both. Of thirteen points in Quintus' version of Odysseus' main speech just seven have counterparts in Ovid's version, one with verbal similarity but none in the same sequence. At the same time, the general style, or colour, of the two versions is markedly different. Vian's conclusion here that the differences between Quintus

\footnotetext{
14 Vian (1959a) 98-101.

15 Vian (1963) XXXIV-XXXV.

16 See Erbse (1971) 567-568.

17 Campbell (1981) passim.

18 Campbell (1981) 118.

19 James / Lee (2000) 80-82, 91-93.
} 
and Ovid are incompatible with direct influence would only be tenable if one shared the view that Quintus lacked sufficient originality to make substantial innovations when using a source.

The belief of Paley and others that Quintus' aim to provide a Homeric-style replacement of some of the early Cyclic epics made him little more than an editor of those same works has long since been abandoned by serious scholars. ${ }^{20}$ There are important differences between the sequence of events in the Posthomerica and that in the Little Iliad and the Sack of Ilium as they are known through surviving summaries. Though it cannot be proved that those epics were not available to him, his departures from them make that the more likely explanation. Accordingly, the first question to be asked about his literary background is from what source or sources he derived his version of the Trojan War, and to this there is no certain answer. Certainly no one would deny that he was a learned poet in view of the wide range of surviving works of Greek literature exploited by him for elaboration of his narrative. But it is an interesting matter of cultural history that it seems to have been unusual, in spite of widespread bilingualism and the overwhelming influence of Greek literature on Latin, for a Greek to make creative use of Latin poetry. That is why, as the foregoing survey shows, many scholars have been reluctant to accept that as the explanation of similarities between the Posthomerica and the Aeneid. Choosing between that explanation and the alternative of a lost common source is often a matter of judging the relative significance of similarities and differences. The greater difficulty of doing this with versions in different languages has obviously contributed to the disagreement of experts for so long. But another factor is prejudice, prejudice concerning Quintus' general quality as a poet, which has led too many to discount originality in his use of sources. That is something we shall try to avoid now in reviewing the relevant passages. These have been most fully and recently treated by Ursula Gärtner. ${ }^{21}$

\section{Review of Passages}

We begin where comparison has been made most often, with Posthomerica 12, which is devoted to the episode of the wooden horse, and the relevant part of Aeneid 2 (13-249). As regards the sequence of events, Virgil's version is substantially closer to Quintus' than was that of the early Greek epics according to their summaries, most importantly in having both Sinon and Laocoon contributing to the Trojans' decision to admit the horse. Sinon, though, is presented very differ-

20 See Vian (1959a) 87-94 for a brief history and discussion of evidence.

21 Gärtner (2005) passim; for comments see n. 29. 
ently by the two poets. ${ }^{22}$ Virgil emphasises his cunning as opposed to the Trojans' gullibility, whilst Quintus makes him much more of a hero, remaining firm under barbaric torture inflicted by the Trojans, something that Virgil's narrator Aeneas naturally avoided. Also, the overwhelming length at which Sinon is presented by Virgil, contrasted with just brief mention of some elements of the story, decidedly in the style of some Hellenistic poetry, is much the most important difference between the two versions. Quintus develops most elements on a similar scale, in the Homeric manner. As for Laocoon, Virgil has him and his sons killed by two snakes sent from Tenedos before the horse's entry. Quintus has him blinded by Athena before the entry and then his sons, not himself, killed by the snakes after it. Also, the snakes come from Calydna instead of Tenedos and go to Apollo's shrine instead of Athena's, though the description of their approach is similar in both versions. A further notable difference is that Virgil just briefly mentions the intervention of Cassandra after the horse's entry, whereas Quintus develops it at dramatic length. If Quintus was influenced by Virgil's version here, he obviously distanced himself from it. In this case the balance of similarities and differences is such as to require an open verdict.

Book 13 of the Posthomerica is devoted to the sack of Troy, and the contrast between Quintus' well constructed but obviously traditional narrative and Virgil's highly idiosyncratic one of the same events at Aeneid 2.250-804 could hardly be greater. The latter has a dramatic unity because of its sustained focus on Aeneas, which is achieved by omission of some traditional elements and original elaboration of others. Nonetheless, there is some correspondence of details between the two versions, most notably in their descriptions of Aeneas' escape from Troy. His carrying of his aged father on his shoulders at Posthomerica 13.317-324 is combined with a description of his young son holding his hand and barely keeping pace, just as it is at Aeneid 2.721-724. Then the immediately following lines (13.326-332) read like an elaboration of the statement made a little earlier in Virgil's narrative (2.632-633) that the flames and the enemies' weapons made way for Aeneas led by Venus, except that there it is Aeneas alone returning to his home. This could hardly suffice to prove Virgil's direct influence if it were not established independently.

For that we turn first to the last book of the Posthomerica (Q.S. 14), which narrates the departure of the Greeks and the partial destruction of their fleet in a storm, caused by Athena for the violation of her sanctuary, the rape of Cassandra by Locrian Ajax. The same storm is recalled by Juno at Aeneid 1.39-45 as a justifying precedent for the storm with which she now wrecks the fleet of Aeneas (Aen. 1.34-123). The account of her enlisting the help of Aeolus to release the

22 On this topic see the contribution of F. Hadjittofi in this volume. 
storm winds is remarkably similar to that of Athena doing the same at Posthomerica 14.466-496, as all critics have noted. There is close similarity in the following: the description of Aeolia as the place where the winds are kept (Aen. 1.51-56, Q.S. 14.474-476); the release of the winds by Aeolus and their initial effect on the sea (Aen. 1.81-86, Q.S. 14.480-490); the alternate lifting and dropping of ships by mountainous waves and the appearance of seething sand (Aen. 1.105-107, Q.S. 14.490-496). In the last of these pictures there is close verbal similarity. Against all this has to be weighed the consideration that Quintus differs from Virgil in having Iris used as an intermediary and Aeolus living with a wife and twelve offspring, in both matters following Homer (respectively $\mathrm{Il}$. 23.198-212 and $O d$. 10.5-7). Since the whole episode is only found in Virgil's and Quintus' versions of the stories, there is surely no reasonable ground for denying that Quintus has taken it from Virgil, whilst exercising the freedom to add Homeric touches in a way that is characteristic of his work. The best that Heinze could offer as an objection to this conclusion was the unjustified claim that Quintus' version has no trace of the lofty, heroic character of Virgil's. ${ }^{23}$ Vian objected that Virgil, by referring explicitly to the same storm that is described by Quintus is identifying his source as the Cyclic epic which, directly or indirectly, lies behind Quintus' narrative. ${ }^{24}$ In other words, we have a case of a shared lost source. But that is unwarranted; there is no reason to see Virgil as doing more than referring to a well-known story - cf. e.g. Od. 4.499-511.

The next passage for consideration is the one used by Keydell to demonstrate Quintus' use of a minor episode in the Aeneid. ${ }^{25}$ At Posthomerica 11.358-407 Odysseus attacks one of the gates of Troy by means of a testudo, the device of covering a body of soldiers with shields interlocked above their heads. There is no earlier mention of a testudo in extant Greek poetry, but the account by Apollonius Rhodius of how the Argonauts used shields and helmets to protect themselves from the bronze feathers dropped by the birds from the Island of Ares (Argonautica 2.1047-1089) is closely analogous and clearly influenced this passage. But the course of action here, with the Trojan defenders first pelting the testudo with stones and other missiles and achieving nothing, and Aeneas breaking it up with a huge rock and more stones, is so closely parallel to the narrative at Aeneid 9.505-518 of how Trojan defenders at first fail and finally succeed against a Volscian testudo that the balance of probability overwhelmingly favours Keydell's case for direct influence. Furthermore, it is important that we recognize the relevance of Virgil's one other mention of a testudo, at Aeneid 2.438-468. There Greeks attack Priam's palace with a testudo and scaling ladders and then

23 Heinze $\left({ }^{3} 1915\right) 76$.

24 Vian (1969) 169.

25 Keydell (1954). 
suffer losses when Aeneas and two others dislodge a turret and hurl it onto them. Aeneas' action in Posthomerica 11.358-473 is very similar, using rocks to repel first the testudo and then an ascent by scaling ladder. Such a remarkable concurrence of influences indicates that Quintus had detailed knowledge of the whole Aeneid.

The same conclusion is to be drawn from a quite incidental reflection of the Aeneid, a point that seems to have escaped the notice of critics. ${ }^{26}$ At Posthomerica 4.423-429 an elaborate simile likens the killing of Troilus to a poppy or a cornstalk cut down by a scythe before it can ripen and seed. It is a rather distant reflection of the relatively brief simile at Iliad 8.306-307 of an already ripe poppy drooping under the weight of seed and rain, to which is likened the drooping head of the dying Gorgythion, who like Troilus was a son of Priam. That Homeric simile was memorably adapted by Virgil at Aeneid 9.434-437, where the neck of the dying Euryalus is likened to a flower cut by a plough or rain-weighted poppies. Part of the difference between the Homeric simile and Quintus' is explicable by the additional influence of Virgil's simile, the action of plough and scythe being a shared feature.

The last passage to be considered for possible Virgilian influence is Posthomerica 12.503-520, the detailing of no fewer than fifteen different sinister portents, or omens, which follow the entry of the horse and presage the destruction of Troy. It has certainly attracted the attention of critics, their conclusions being consistent with those already noted for other passages. ${ }^{27}$ The likelihood that Quintus reflects a tradition of portents in this particular context is indicated by the fact that in the ancient prose narrative titled Diary of the Trojan War, a supposed eyewitness account by the fictional Dictys of Crete, at a slightly earlier point, before the horse's construction, the Trojans' sacrifices cannot be burnt and fall to the ground (5.7). Also, Virgil records portents following the theft of the Palladium, the image of Athena whose presence guaranteed the safety of Troy (Aen. 2.171-175). In earlier Greek poetry there are precedents for a few of the portents listed here, such as sacrifices that will not burn (Sophocles, Antigone 1006-1011), statues sweating blood and strange sounds in temples (Apollonius Rhodius, Argonautica 4.1284-1285). What is remarkable in the present passage is the accumulation of so many portents, fifteen, and for a precedent we must turn to Latin poetry. There the most closely comparable example is Virgil's description, at slightly greater length, of sixteen kinds of portents associated with the death of Julius Caesar at Georgics 1.466-488, which became the prototype for similar

26 Including Gärtner (2005).

27 See Keydell (1963) 1288; Vian (1959a) 69-70; Campbell (1981) 169-170. See also Kakridis (1962) 109-110, who rejects direct use of Latin sources in this case. 
passages in later Roman epics. ${ }^{28}$ Most of Virgil's portents are different from Quintus', but two are the same - weeping statues of gods and wolves howling inside cities. Given the evidence for Quintus' knowledge of both the Aeneid and the Metamorphoses, it is hardly credible that he was not influenced by Virgil in this case. If we look for a reason why he should have regarded that passage of the Georgics as specially relevant to the subject of his own epic, it is not far to seek. Shortly afterwards, at Georgics 1.501-502, Virgil associates the civil wars with collective guilt inherited by Rome from Troy: "Long since our blood has paid enough for the treachery of Laomedon and Troy" (satis iam pridem sanguine nostro / Laomedonteae luimus periuria Troiae). ${ }^{29}$

\section{Lessing and Laocoon}

I shall conclude this study by considering the relevance to it of a classic of German literature, Lessing's Laokoon, subtitled Über die Grenzen der Mahlerey und Poesie, which was written between 1760 and 1765 and published in 1766 . Among the work's impressive display of classical scholarship a prominent place is occupied by comments on Quintus' epic, which are refreshingly free from the prejudices of some later scholarship. These comments occur both in the most important discussion, that of the relationship between the famous marble Laocoon sculpture and Virgil's narrative of the same event, as well as in the following two different discussions. First, in chapter 12 Lessing notes that Quintus' battle between the Olympian deities, Theomachy (Q.S. 12.162-218), implies criticism of its model in the Iliad $(20.4-74 ; 21.385-520)$ by not allowing the deities' bodies to be injured by the rocks that are thrown, thereby giving a more sublime notion of their bodies, though at the expense of making their weapons seem ridiculous. Secondly, in chapter 23 Lessing finds it instructive to compare two episodes involving the ugly, abusive Thersites. In Iliad 2.211-277 his abuse of Agamem-

28 See Mynors (1990) 92. Ovid's imitation of Virgil at Met. 15.783-798 could also have been known to Quintus.

29 After completion of the foregoing, which was first presented as a paper at the $26^{\text {th }}$ Conference of the Australasian Society for Classical Studies, University of Otago, Dunedin, New Zealand, Jan. 30 - Feb. 3, 2005, under the title Virgil's Influence on Quintus of Smyrna, Gärtner's treatment of the same subject was published. It agrees in all essentials with the conclusions drawn in my own review of passages. Gärtner examines many other passages for the possibility of direct influence from the Aeneid, but of these there are only two that, in my judgement, amount to near certainty: at Q.S. 1.335-341 the description of Penthesilea's entry into battle has a detailed similarity to the same of Camilla at Aen. 11.648-655 that is only plausibly explained by the latter's influence (Gärtner [2005] 53-56); much the same may be said of the applications of the simile theme of a cauldron of boiling water at Q.S. 5.379-385 (to Ajax's madness) and at Aen. 7.461466 (to Allecto's maddening of Turnus; Gärtner [2005] 96-100). 
non is punished with a beating from Odysseus and our sense of justice is satisfied. But in Posthomerica 1.722-766 Achilles strikes Thersites dead for mocking him over his erotic feelings for the slain Amazon queen Penthesilea, and this time the approval of the Greek army can only offend our sense of justice.

The principal question of Lessing's Laokoon is whether the sculpture was conceived as an illustration of Virgil's narrative in Aeneid 2.13-249 or, alternatively, the sculpture was already known to Virgil. This is mainly discussed by Lessing in chapters 5 and 6 . His conclusion in favour of Virgil's priority has been proved wrong by independent evidence for the date of the sculpture. ${ }^{30}$ The matter is complicated by the further question of whether it is an original composition or a copy. The latest possible time of manufacture is approximately contemporary with the Aeneid. Virgil died in 19 B.C., and the only ancient record of the sculpture, that of Pliny the Elder (Natural History 36.4.11), is nearly a hundred years later. It was then a famous work of art in the palace of the emperor Titus at Rome, where it was excavated in January 1506 and seen by Michelangelo, then aged thirty. As for the possible influence on Quintus either of the sculpture itself or of some similar iconography, the verdict must surely remain open. Of greater interest for our purposes are the considerations of literary history used by Lessing. As we have already noted, one of the differences of Quintus' corresponding narrative in Posthomerica 12.353-499 is that only Laocoon's sons are devoured by the snakes, not Laocoon himself. This is taken by Lessing as belonging to a uniform Greek tradition, against which Virgil's version was an original innovation. He could not have known that the earlier Greek tradition was divided on precisely this point, because it only came to light in 1788 with publication of the ancient summaries of the early Trojan epics in Villoison's edition of the great Venetian manuscript of the Iliad. ${ }^{31}$

The other difference of Quintus' version of the Laocoon story from Virgil's is that before the arrival of the snakes Laocoon's opposition to the wooden horse is punished by a rapid and painful onset of blindness, caused by Athena. Although this is duly recorded by Lessing, he does not ask whether it is more likely to have belonged to the earlier Greek tradition or to have been an innovation on the part of Quintus, and this question has not been adequately considered by later critics. A precedent for it was provided by one version of the blinding of the Greek seer Tiresias, namely that it was inflicted by Athena as punishment for his accidentally seeing the goddess naked (Callimachus, Hymn 5.77-89). An association between the two stories was all the more natural in view of the tradition that Laocoon too

30 See Austin (1964) 96-97; Smith (1993) 199-201.

31 Villoison (1788) passim. According to Vian (1959a) 87 the summaries were first published in 1785. 
was guilty of a sexual offence. ${ }^{32}$ But there is no evidence that blinding had been a feature of the Laocoon story before Quintus, and the question of originality can only be judged on the basis of internal factors. I begin with my translation of the relevant lines: ${ }^{33}$

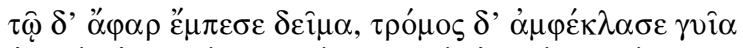

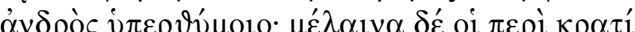

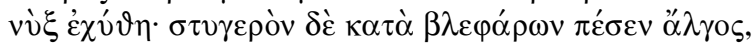

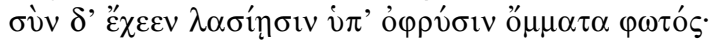

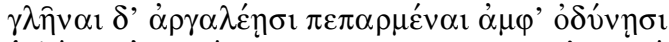

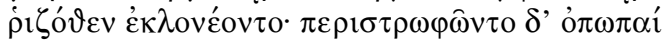

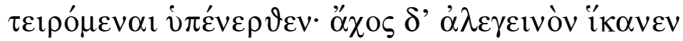

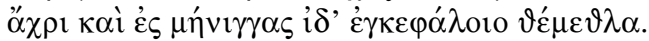

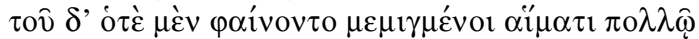

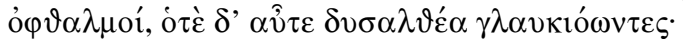

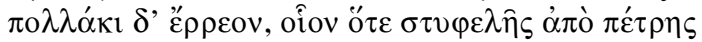

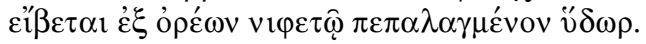
$\mu \alpha \imath \mu^{\prime} \varepsilon^{\prime} v \varphi \delta$ '

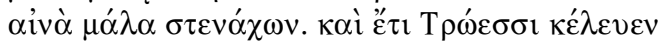

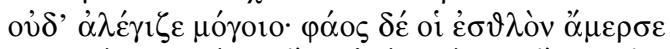

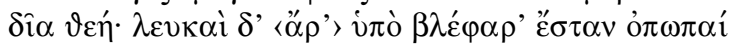

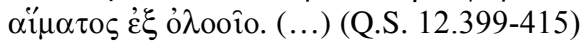

At once he was seized by terror and trembling shattered

The strength of the proud man's limbs. Around his head was spread The blackness of night. A horrible pain shot through his eyelids

And disordered the eyes beneath his shaggy brows.

Stabbed with piercing pangs up from their roots,

His pupils grew confused. His eyeballs started rolling

With the deep affliction, and agonizing pain

Penetrated the membranes at the base of his brain.

His eyes appeared alternately extremely bloodshot

And, in contrast, covered with a sickly glaze.

From them came a frequent discharge, just like water

Sprinkled with snow which flows from a rugged rock in the hills.

He seemed to be demented, seeing everything double

And uttering dreadful groans. But still he exhorted the Trojans,

Disregarding his misery. Robbed of their blessed light

By the goddess, his eyes grew fixed and white beneath their lids

After the fatal bleeding. (...)

The best English commentary on Aeneid 2, that of R. G. Austin published in 1964, reflects the prevailing academic prejudice against Quintus by referring to

32 Thus Servius on Verg. Aen. 2.201.

33 James (2004) 199. 
his version of the Laocoon story as "dreary horrors". ${ }^{34}$ I wonder how many unprejudiced readers have found it dreary. The remarkable detail of the present passage is in fact an accurate description of an accelerated attack of congestive glaucoma. ${ }^{35}$ If we look for a poetic reason for the emphasis placed on blindness, it is not far to seek. The physical blinding of Laocoon foreshadows the metaphorical blinding of the Trojans to their approaching doom, which is emphasised in the following narrative and actually includes impairment of their eyesight by an excess of wine (Q.S. 13.10-13). But the crucial question for originality is what we can identify as distinctively characteristic of Quintus' work. Very similar indeed is the detailed physiological description of the onset of mental illness in Ajax at Posthomerica 5.322-329, which likewise seems to be an original embellishment of a traditional story. ${ }^{36}$ Even more directly relevant, however, is an extended simile in Posthomerica 1 (76-82), one of the few similes in the whole epic that seem to be original in subject matter. The partial comfort felt by king Priam at the arrival of Penthesilea with her Amazon army is likened to the partial recovery of a man from a condition that is probably glaucoma. This is my translation: ${ }^{37}$

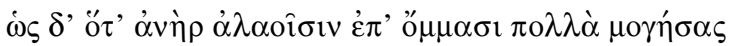

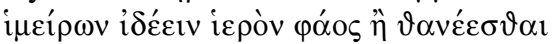

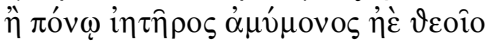

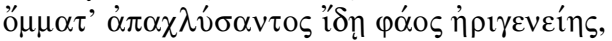

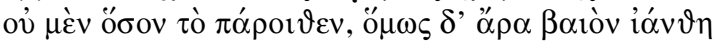

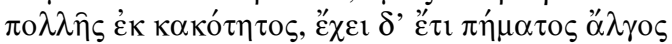

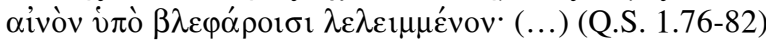
As a man who has suffered much because of blindness
And longs for death if he cannot see the blessed light,
Either through some good doctor's work or because a god
Has removed the mist from his eyes, now sees the light of day;
Not as well as before, but he's comforted a little
After all his suffering, though pangs of smarting pain
Linger beneath his eyelids; (...)

In both the simile and the Laocoon episode we must distinguish between two different aspects. On the one hand, indulgence in so much realistic description at moments of dramatic importance belongs to the Homeric manner cultivated by Quintus, something very different from the dramatic concentration of Virgil's

34 Austin (1964) 95.

35 See Campbell (1981) 139-140, where the unjustified assertion is made that the passage is "certainly Hellenistic in origin".

36 See James / Lee (2000) 13 and 107-108.

37 James (2004) 5. 
narratives. On the other hand, the choice of subject matter has every appearance of reflecting a personal interest, one that in Quintus' time may have seemed daringly modern. ${ }^{38}$ But for some scholars the very fact that Quintus imitates Homer puts his work below the level of serious literature, a devaluation that was given its most extreme and influential expression by Wilamowitz in his history of Greek literature published in 1905. He regarded Quintus' 'dreary parroting' ("das öde Nachplappern") as a form of literary prostitution. ${ }^{39}$ In order to see this in perspective we need to remember that Wilamowitz even regarded parts of the Odyssey as exhibiting a degeneration of epic language into empty formulae, and for a similar reason he saw little merit in the newly discovered choral lyrics of Bacchylides. ${ }^{40}$ It is true that Quintus' epic, unlike, for example, Apollonius Rhodius' Argonautica or Nonnus' Dionysiaca, does not seek to be different in style from the Homeric epics. Precisely for that reason, however, anyone who can read Homer has no difficulty in reading Quintus, which is certainly not the case either with Apollonius or with Nonnus.

Finally, one more source of prejudice against Quintus' epic is the idea that anything as late as a thousand years after Homer must be inferior. Wilamowitz, in the passage already mentioned, speaks of the old age ("Greisenalter") and second childhood of heroic epic. Another eminent scholar, Lloyd-Jones, used the epithet "anaemic" to describe the Posthomerica, ${ }^{41}$ anaemia being a common condition of old age. Referring to this, a recent reviewer of my English verse translation observes that "this seems particularly inappropriate given the creative variety marking the descriptions of bloodshed in Quintus' spectacular, sophisticated and gruesome narrative [...] Even readers who thought they were inured to Greek epic carnage may feel as if they were watching a film about the fall of Troy directed by Quentin Tarantino; Quintus was [...] competing with the entire tradition of ancient aestheticized violence [...] He takes an unhomeric pleasure in extreme suffering from causes other than wounds inflicted on the battlefield, evident in the torture of Sinon and the death pangs of Laocoon."42

38 The two 'glaucoma passages' are also discussed by L. Ozbek in her contribution to this volume.

39 Wilamowitz (1905) 216.

40 Wilamowitz (1903) 54; Maehler (1982a) X.

41 Lloyd-Jones (1969) 101.

42 Hall (2005) 4-6. 
